\title{
On the Beginning Times of Thunders in the Cloud Seeding Experiments
}

\author{
by \\ E. Uchida \\ Meteorological Research Institute, Tokyo \\ (Received February 3, 1958)
}

\begin{abstract}
It was found that thunders were apt to break out in succession towards the leeward along the path of the drifting silver iodide smoke in cloud seeding experiments and some explanation was tried about it in the light of recent knowledge of thunderstorms.

The height and temperature of the level at which the top of the smoke reached cumulo-nimbus clouds and the process of the outbreak of thunders after the arrival of the smoke in the clouds were discussed.
\end{abstract}

\section{Introduction}

In the Last Report on the Cloud Seeding Experiments of Tokyo Electric Power Company in the Summer of 1952, (Physical Meteorology Laboratory, 1953), it was pointed out that thunders broke out in succession towards the leeward along the path of the drifting silver iodide smoke on 3rd and 4th of August, though no distinct effect of the seedings was seen in precipitation.

Such activity of thunders had not been seen on the non-seeding days, 5 th and 6th, for example, notwithstanding that the direction of the wind aloft had been the same (i.e. south-west) all these seeding and non-seeding days, and thus the thunders witnessed might be considered as the result of the cloud seedings.

In this paper some explanation will be given about it in the light of recent researches of thunderstorms.

\section{On the results of the cloud seeding experiments}

On the non-seeding days, August 5 and 6, for example, the number of the occurrences of thunderstorm was small, and no successive thunders towards the leeward as pointed out above was noticed.

Both on August 3 and 4, when cloud seedings were done, heat frontal tounderstorms occurred here and there, and increased in number in the afternoon. Especially on August 3 cumulo-nimbus clouds developed fairly well in the vicinity of Lake Inawashiro in the direction of the drift of silver iodide smoke.

The most plausible paths of the top of silver iodide smoke in the experiments of cloud seeding in Kanto and Chubu Districts in the summer of 1952 have been 
determined from the wind aloft observed at several points in the experiment area, assuming that the top of the smoke rises at a vertical speed of $0.5 \mathrm{~m} / \mathrm{sec}$ (TAKAHAshi, 1954). The path of the smoke on August 3 and 4 runs toward the midst of one of the group of thunderstorms.

This group of thunderstorms has an angular breadth of about $30^{\circ}$ against the smoke source, namely Mt. Shirane, and this angle also coincided with the case of the abnormal rainfalls in the other experiments (Physical Meteorology Laboratory, 1953, TAKAHASHI, 1954).

The directions of the winds aloft were south-west on both days.

\section{1) August 3 (Fig. 1)}

The smoke was released from $9 \mathrm{~h} 00 \mathrm{~m}$ to $17 \mathrm{~h} 10 \mathrm{~m}$ and the total amount of combustion of silver iodide was $3.90 \mathrm{~kg}$.

According to the observations of the winds aloft at $10 \mathrm{~h}$ and $15 \mathrm{~h}$, the silver iodide smoke entered the region of thunderclouds when the top of smoke reached the level of $7.4 \mathrm{~km}$ above ground (i.e. the temperature of $-10^{\circ} \mathrm{C}$ in air), and the thunders broke out successively down the path of the smoke increasing in number. The time of the beginning of thunders versus the horizontal distance from Mt. Shirane is shown in Fig. 2. The thunders which had broken out before the arrival of, the smoke shown by solid line (i.e. the left side of the time-distance line) are

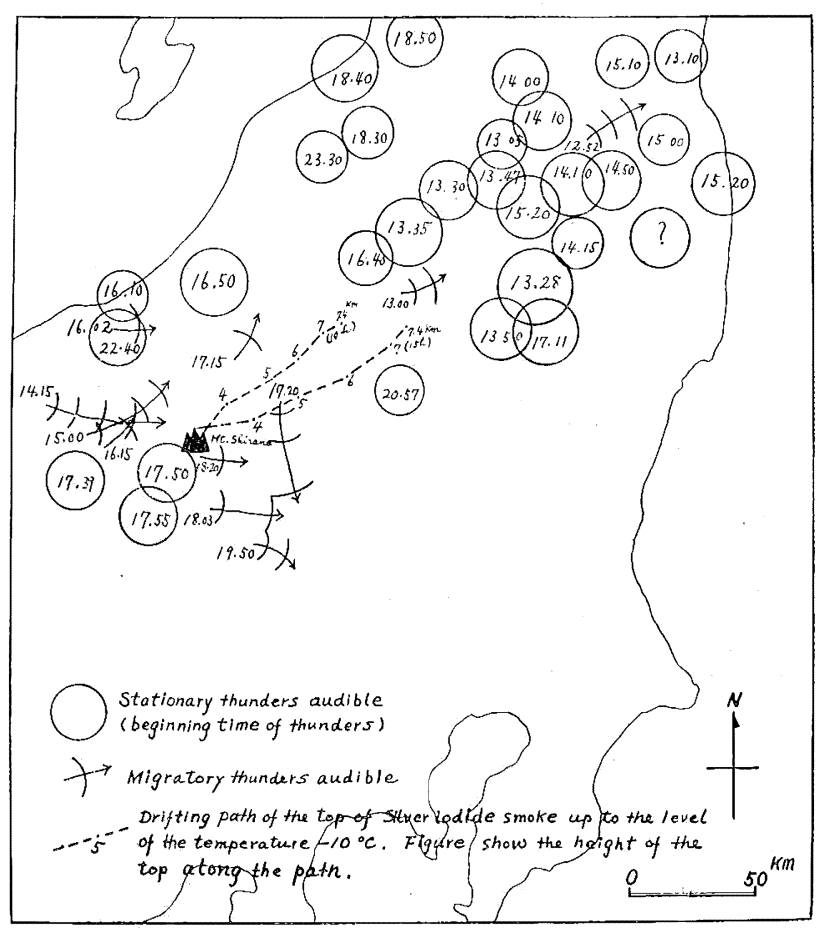

Fig. 1. Distribution of the beginning time of thunders on August 3, 1952, when cloud seeding was experimented. considered to have occurred spontaneously. The greater number of thunders, however, occurred within the seeded area and it will be noticed that the first stimulation was effective for the outbreak of thunders, because the thunders had begun to occur in succession along the time-distance curve of the smoke in Fig. 2.

Since the particles of silver iodide smoke begin to act as ice forming nuclei in supercooled clouds at about $-5{ }^{\circ} \mathrm{C}$ in temperature (the particles of silver iodide of 0.1 to $0.2 \mu$ in diameter predominated in the distribution of particles at Mt. Shirane and in this range of diameter the particles of silver iodide become effective at about $-5^{\circ} \mathrm{C}$ in temperature), of course, the smoke of higher density below the top of the smoke would also be drawn into thunderclouds-cumulo-nimbus at the 


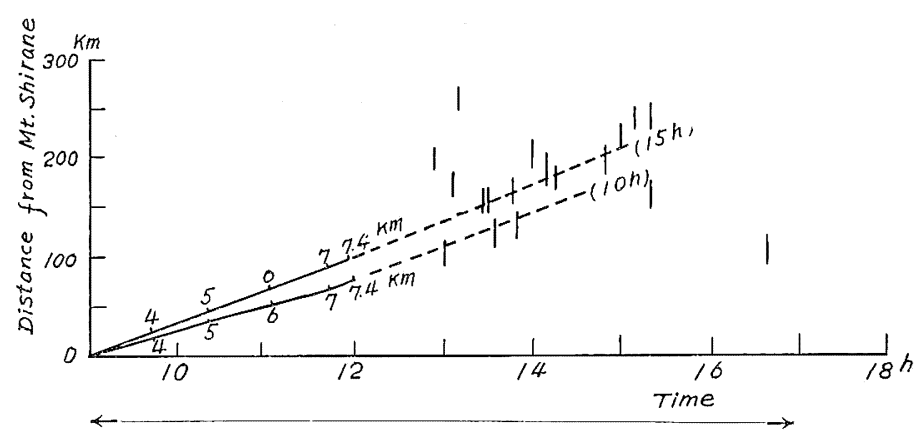

Fig. 2. Beginning time of thunders, arrival time of silver iodide smoke, and the distance from Mt. Shirane, arrows showing the period of the release of silver iodide smoke on Mt. Shirane.

first or middle stage according to the observations--and act as ice forming nuclei at the temperature below $-5^{\circ} \mathrm{C}$ (i.e. at the level above $6.6 \mathrm{~km}$ above ground).

Then it is likely that the top of smoke would drift leewards maintaining the level of about 7 to $8 \mathrm{~km}$ above ground because it is thought that the smoke would not ascend further. As the maximum wind velocity up to $10 \mathrm{~km}$ above ground was $9.6 \mathrm{~m} / \mathrm{s}$ at $7 \mathrm{~km}$ above ground (at $10 \mathrm{~h}$ ) or $12.5 \mathrm{~m} / \mathrm{s}$ at $6 \mathrm{~km}$ above ground (at $15 \mathrm{~h}$ ), the smoke would diffuse below the level of about 7 to $8 \mathrm{~km}$ above ground.

Besides, the thunderstorms near Mt. Shirane were put out of consideration as they were thought to belong in the other group even if they occurred along the path of the drifting smoke.

\section{2) August 4 (Fig. 3)}

The smoke was released from $2 \mathrm{~h} 50 \mathrm{~m}$ to $15 \mathrm{~h} 20 \mathrm{~m}$ and the total amount of combustion of silver iodide was $7.02 \mathrm{~kg}$. According to the observation of the winds aloft at $15 \mathrm{~h}$, the time-distance curves of the smoke is completely parallel with that of thunders, but there is a considerable gap of time between the arrival of the smoke and the outbreak of thunders. Though the smoke was

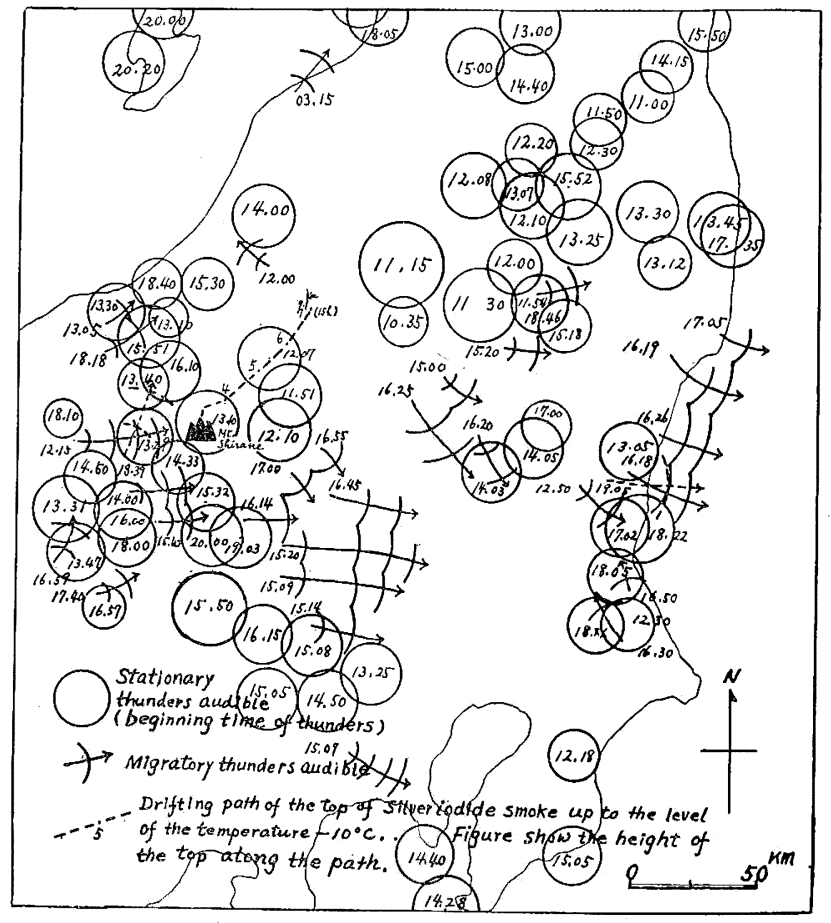

Fig. 3. Distribution of the beginning time of thunders on August 4, 1952, when cloud seeding was experimented. 
released from $2 \mathrm{~h} 50 \mathrm{~m}$, it reached the level of 7 to $8 \mathrm{~km}$ above ground before cumulo-nimbus clouds fully developed in the morning, so the smoke was not effective because of the insufficient convection of the air.

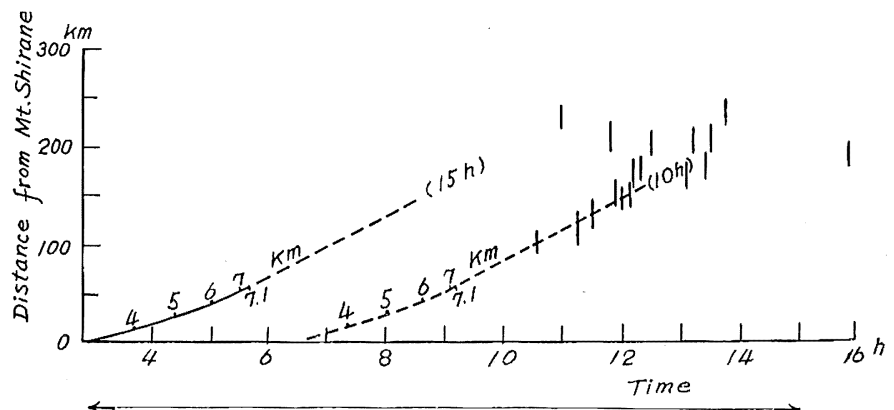

Fig. 4. Beginning time of thunders, arrival time of silver iodide smoke, and the distance from Mt. Shirane, arrows showing the period of the release of silver iodide smoke on Mt. Shirane.

Since the thunders would break out after the arrival of the smoke, the timedistance curve of the smoke was moved parallel so as to agree with that of thunders which was drawn by broken curve, and the effective smoke must be released from about $6 \mathrm{~h} 30 \mathrm{~m}$. The smoke entered the region of thunder-clouds when the top of smoke reached the level of $7.1 \mathrm{~km}$ above ground (i.e. the temperature of $-10^{\circ} \mathrm{C}$ in air).

Then it is thought that the top of the smoke drifted in the same manner and their particles acted as ice-forming nuclei at temperatures below $-5^{\circ} \mathrm{C}$ (i.e. at levels higher than $6.2 \mathrm{~km}$ above ground.)

The maximum wind velocity was $9.3 \mathrm{~m} / \mathrm{s}$ at $9 \mathrm{~km}$ above ground (at $15 \mathrm{~h}$ ), and only the stimulation at the arrivel of the smoke seems to have been effective for the outbreak of thunders.

\section{Summary of recent researches of thunderstorms}

The present author would like to explain the above results further in the light of recent researches of thunderstorms, especially for the relation between the time of the outbreak of thunders and the growth of ice crystals after the seeding of ice-forming nuclei into a thundercloud.

The characteristics of thunderstorms relevant to the present study which have been revealed by recent researches are summarized in the following:

a) The process of electric charge separation in a thundercloud is in close relation to the development of precipitation, especially rigid precipitation (i.e. hailstones, snow pellets etc.). Precipitating particles must be able to fall through an ascending air current with a speed of severa meters per second (MASON, 1953). The most heavy rigid precipitation occurs in a central area as narrow as $2 \mathrm{~km}$ in radius in a thunderstorm (KUETTNER, 1950).

b) Though electric charge separation occurs already at the level of $-5^{\circ} \mathrm{C}$ to $-10^{\circ} \mathrm{C}$ in temperature, the radar echo of precipitation (the particles are estimated 
about $200 \mu$ in diameter and $10^{4}$ particles per cubic meter in the air) appears at the level of $-12^{\circ}$ to $-14^{\circ} \mathrm{C}$ in temperature.

Electric charge must be separated so swiftly and sufficiently that a thunderstorm can break out within about 12 to 15 minutes after its radar echo appears and begins to move. The temperature at the level of the outbreak of a thunderstorm is about $-30^{\circ}$ to $-40^{\circ} \mathrm{C}$. At the same time precipitation occurs at the cloud base and thunderbolt starts within 2 to 3 minutes (WORKMAN and REYNOLDS, 1950). This stage is the beginning of the mature stage of a thunderstorm.

c) In the mature stage of a thunderstorm the top of the cloud reaches often the tropopause and the cloud base is at the level below $0^{\circ} \mathrm{C}$ in temperature. As to the electric charge distribution in a thundercloud the centre of the lower region of negative electric charge is at the level of $-5^{\circ} \mathrm{C}$ and the centre of the upper region of positive electric charge is at the level of several kilometers above it and at the level below $-40^{\circ} \mathrm{C}$. Other regions of positive electric charge are often found near the cloud base. As to the process of electric charge separation, only the electrical phenomena accompanying the formation and growth of hailstones or snow pellets have been much discussed, but here they are left as problems for future study. From the report that the discharging region region which is charged in the negative (Malan and Schonland, 1951) extends up to the level of $-40^{\circ} \mathrm{C}$ in temperature, but does not exceed this level, and that supercooled water droplets are found at the temperature above $-40^{\circ} \mathrm{C}$, the results of the experiments of FINDEISEN (1940) and others seem to explain well this phenomenon of electric charge separation. According to their experiments ice pellets are charged in the negative and its surrounding air is charged in the positive in a supercooled region.

d) The average duration of precipitation from one cell in a thundercloud or its electric activity is about $30 \mathrm{~min}$.

There are three stages in the activity of a thunderstorm, namely

1) Cumulus stage for 10 to 15 minutes,

2) Mature stage for 15 to 30 minutes,

3) Dissipating stage for 30 minutes (WichmanN, 1952).

\section{On the relation between the turbulent diffusion of silver iodide smoke in the air and the beginning times of thunders}

On August 3 and 4 in the cloud seeding experiments, the silver iodide smoke entered the region of thunderclouds when the top of smoke reached respectively the level of 7.4 and $7.1 \mathrm{~km}$ above ground (i.e. both the temperature of $-10^{\circ} \mathrm{C}$ in air). The temperature in a thundercloud at its mature stage is $-13^{\circ}$ to $-15^{\circ} \mathrm{C}$ at the level of 7.1 to $7.4 \mathrm{~km}$ above ground (Workman and Reynolds, 1950). This temperature is quite suitable for the appearance of a radar echo (i.e. $-12^{\circ}$ to $\left.-14^{\circ} \mathrm{C}\right)$.

Then the order of the density of silver iodide smoke when it entered the region of thunderclouds is estimated as follows. It is assumed that the smoke diffused on the law of diffusion given by RoBerT (SutTon, 1949) because it is thought that the atmosphere was isotropic and the shear caused by the ground had no effect since the source of smoke was at the level of $2,100 \mathrm{~m}$ above ground. When the rectangular coordinate is fixed so that the continuous point source is 
taken at the generating point of smoke, $x$ is measured in the direction of the mean wind, $y$ across wind and $z$ vertically, the smoke concentation $\chi\left(\mathrm{gr} / \mathrm{m}^{3}\right)$ on any point $(x, y, z)$ is derived in equation (1)

$$
\chi(x, y, z)=\frac{Q}{4 \pi K x} \exp \left[-\frac{U\left(y^{2}+z^{2}\right)}{4 K x}\right],
$$

where $Q(\mathrm{gr} / \mathrm{sec}) \quad \cdots \cdot$ the strengh of source

$K\left(\mathrm{~cm}^{2} / \mathrm{sec}\right) \cdots \cdots$.eddy diffusion coefficient

(thought to be constant in this case)

$U(\mathrm{~m} / \mathrm{sec}) \quad \cdots \cdot$ mean wind velocity

$x, y, z(\mathrm{~m}) \quad \cdots \cdot$ coordinates.

In order to estimate $K$, the method of the graphical solution of the problem on the diffusion by turbulence (TAKAHASHI, 1941) is used. Boundary of diffusion is given in equation (2) on the same coordinate

where

$$
\begin{gathered}
H=\sqrt{6} \sqrt{K \frac{x}{U}}, \\
H^{2}=Y^{2}+Z^{2} .
\end{gathered}
$$

On August 3 and 4 the groups of thunders described above occurred from $x=100 \mathrm{~km}$, $y \leqq \pm 25 \mathrm{~km}$ and the diffusion angles in horizontal were about $30^{\circ}$. If these groups are thought to have occurred on accout of the seedings of smoke, the most suitable value of $K$ is of the order of $10^{8}\left(\mathrm{~cm}^{2} / \mathrm{sec}\right)$ from equation (2), where each mean wind velocity on both days (the mean values from $2 \mathrm{~km}$ to $8 \mathrm{~km}$ on ground) were $8.2 \mathrm{~m} / \mathrm{s}$ and $6.0 \mathrm{~m} / \mathrm{s}$.

This order of $K$ agrees with the value estimated from diffusion of volcanic ashes by RICHARDSON (1926).

The quantities $Q, U, Z$ in equation (1) are shown in Table 1.

Table 1.

\begin{tabular}{l|l|l}
\hline & Aug. 3 & \multicolumn{1}{|c}{ Aug. 4 } \\
\hline$Q$ & $0.1327 \mathrm{gr} / \mathrm{sec}$ & $0.1560 \mathrm{gr} / \mathrm{sec}$ \\
$U$ & $8.2 \mathrm{~m} / \mathrm{s}$ & $6.0 \mathrm{~m} / \mathrm{s}$ \\
$Z$ & $7,400 \mathrm{~m}$ & $7,100 \mathrm{~m}$ \\
\hline
\end{tabular}

\begin{tabular}{|c|c|c|}
\hline$x=100 \mathrm{~km}$ & Aug. 3 & Aug. 4 \\
\hline$y=0 \mathrm{~km}$ & 3. $18 \times 10^{3} / \mathrm{m}^{3}$ & $3.88 \times 10^{3} / \mathrm{m}^{3}$ \\
\hline 10 & $2.59 \quad 1$ & $3.34 \prime \prime$ \\
\hline 20 & 1.40 & 2.13 \\
\hline$x=200 \mathrm{~km}$ & Aug. 3 & Aug. 4 \\
\hline$y=0 \mathrm{~km}$ & 1.68 & 2.02 \\
\hline 10 & 1.52 & 1.87 \\
\hline 20 & 1.12 & 1. 49 \\
\hline
\end{tabular}

The smoke concentrations $\chi$ are given in Table 2 .

Table 2 
Here the mean mass of one smoke particle was estimated $2.97 \times 10^{-15} \mathrm{gr}$. from the observation at Mt. Shirane.

In this case eddy diffusion coefficients along $y$ and $z$ axes are equal but it is likely that eddy diffusion constant along $Z$ axis is less than that along $y$ axis in the atmosphere. So the smoke densities estimated above are expected to increase. Since the wind direction, moreoer, changed slightly during the release of smoke, the smokes of the order of $10^{3} \sim 10^{4} / \mathrm{m}^{3}$ may have affected the groups of thunders described above.

The order of the mean density of the smoke estimated above agrees completely with that of precipitation particles when a radar echo appears at the level of $-12^{\circ}$ to $-14^{\circ} \mathrm{C}$ in temperature. Though the growth of ice crystals produced by the smoke cannot be estimated from the present data, it would take 2 or 3 minutes for ice crystals to grow to the size of $200 \mu$ in diamter from the seeding into a cloud.

The level of 7.1 or $7.4 \mathrm{~km}$ above ground also corresponds to the middle region between the upper and the lower centre which are charged contrary to each other, and moreover this is the region which heavy precipitation developes and electric charge separation occurs most strongly.

The interval between the arrival of the smoke and the outbreak of thunders is not clear because the path and drifting speed of the smoke are not definite. The ascending speed of air has been estimated in any local portion in a thundercloud at 8 to $10 \mathrm{~m} / \mathrm{s}$ at the level of $0^{\circ} \mathrm{C}$ and at 15 to $17 \mathrm{~m} / \mathrm{s}$ at $-10^{\circ} \mathrm{C}$ in temperature (WICHMANN, 1952), but the mean speed should be 2 to $4 \mathrm{~m} / \mathrm{s}$ when it takes 12 to 15 minutes for ascending from the level of -12 to $-14^{\circ} \mathrm{C}$ to the level of $-30^{\circ}$ to $-40^{\circ} \mathrm{C}$ above ground. The ice crystals produced by the smoke are thought to develope into hailstones which are charged negative and are able to fall down in the ascending air. Since the size of hailstones which enables them to fall down in an air current ascending at a speed of 3 to $4 \mathrm{~m} / \mathrm{s}$ is about $1 \mathrm{~mm}$ in diameter, hailstones would develope easily from $200 \mu$ to $1 \mathrm{~mm}$ in diameter in the duration of 12 to 15 minutes before the outbreak of thunders.

According to the observation, the cumulo-nimbus clouds were in the first or middle stage and a few of cumulo-nimbus clouds were in the mature stage. So the silver iodide smoke released above Mt. Shirane seems to have effectively stimulated in succession those cumulo-nimbus clouds along its driftng path. Moreover seedings seem to have been effective only when convections had developed to some suitable degree.

The average duration of thunderstorms was about 2 hours on August 3 and this is slightly longer than that of Wichmann (1952).

As for the theory that frontal or heatfrontal thunders are apt to break out in succession only when some front passes from west to east we could not contirm it over the whole area on either day.

In order to examine the effect of the passing of any front, the author summarized this effect in Table 3 on the basis of the reports of thunderstorms in the period of 1951 to 1956 . Since 1952 cloud seeding experiments have been carried out in each district. Table 3 presents the data summarized from thunders that occurred more than 10 times in a day in the region including the Kanto, Nagano and Shizuoka districts. 
Table 3. Classification of thunders that occurred more than 10 times in a day in the period of 1951 to 1956.

\begin{tabular}{|c|c|c|c|c|c|c|}
\hline \multirow{5}{*}{ Heat thunders } & \multirow{5}{*}{$\begin{array}{l}\text { Total amount } \\
\text { of days that } \\
\text { the thunders } \\
\text { occurred } \\
\quad 57\end{array}$} & \multirow{4}{*}{$\begin{array}{l}\text { Number of days that } \\
\text { thunders occurred } \\
\text { in succession to a } \\
\text { certain horizontal } \\
\text { direction } \\
\qquad 7\end{array}$} & \multirow{4}{*}{$\begin{array}{l}\text { Number of seed- } \\
\text { ing days } \\
5 \\
\text { Number of non- } \\
\text { seeding days } \\
2\end{array}$} & (i) & 0 & \\
\hline & & & & (ii) & 5 & (A) \\
\hline & & & & (i) & 2 & \\
\hline & & & & (ii) & 0 & \\
\hline & & $\begin{array}{l}\text { Number of days that } \\
\text { thunders occurred } \\
\text { at random } \\
\qquad 50\end{array}$ & & & & \\
\hline \multirow{5}{*}{$\begin{array}{l}\text { Heat-frontal } \\
\text { thunders }\end{array}$} & \multirow{5}{*}{59} & \multirow{4}{*}{$\begin{array}{c}\text { in succession } \\
10\end{array}$} & \multirow{2}{*}{$\underset{6}{\text { seeding days }}$} & (i) & 4 & \\
\hline & & & & (ii) & 2 & (B) \\
\hline & & & \multirow{2}{*}{$\begin{array}{c}\text { non-seeding } \\
4\end{array}$} & (i) & 4 & \\
\hline & & & & (ii) & 0 & \\
\hline & & at random & - & & & \\
\hline \multirow{5}{*}{$\begin{array}{l}\text { Frontal } \\
\text { thunders }\end{array}$} & \multirow{5}{*}{73} & \multirow{4}{*}{$\begin{array}{c}\text { in succession } \\
18\end{array}$} & \multirow{2}{*}{$\begin{array}{l}\text { seeding days } \\
5\end{array}$} & (i) & 5 & \\
\hline & & & & (ii) & 0 & (C) \\
\hline & & & \multirow{2}{*}{$\begin{array}{c}\text { non-seeding days } \\
13\end{array}$} & (i) & 13 & \\
\hline & & & & (ii) & 0 & \\
\hline & & at $\operatorname{random}_{55}$ & - & & & \\
\hline
\end{tabular}

where (i) denotes the number of days that thunders occurred in succession to a certain horizontal direction in a general area,

(ii) denotes the number of days only in a local area.

In this table the number of thunders that occurred in succession in a general area tends to increase comparatively on the case of frontal thunders than heat thunders. The directions that thunders occurred in succession were in most cases form westward to eastward and there was no case that thunders occurred in succession to a certain direction at any local area on non-seeding days.

Heat thunders are apt to occur at random in each area and there was only 2 cases that occurred in a general area on non-seeding days. So it is favourable to distinguish the present effect on seeding days when heat thunders occurred. As it is shown by (A) there are 5 examples that the immediate effect of seeding was observed in a local area on days when heat thunders occurred, in case which the angle of diffusion of silver iodide smoke was thought leeward by about $30^{\circ}$ from the smoke source and no general effect was seen on any of thesedays. Two more examples might be associated with seeding experiments in spite of unsatisfagtory data but three other examples were so unlikely that the confirmation could not be given. 
On seeding days with heat-frontal thunders, there were 4 cases that the effect was observed in a general area and 2 cases that the effect was observed in a local area. These latter, denoted by (B), were fortunately on August 3 and 4 in 1952.

On both seeding and non-seeding days with frontal thunders the effect was observed only in a generel area.

Hence, so far as this effect is concerned, it seemes that seedings were fit for days with heat thunders or for some of the days with heat-frontal thunders but on days with frontal thunders no distinct effect of seeding was observed.

On the question whether the passage of some front which does not appear in the weather chart may have anything to do with this local effect, in other words, whether an appreciable dynamical agent will exceed the physical one caused by the seeding, a more detailed analysis than the present will be required.

The growth of ice crystals and the time interval from the seeding into a cloud to the outbreaking of thunders, will be made clear by the repetition of cloudseeding experiments in future.

Acknowledgement_— The author wishes to acknowledge to Dr. Y. TAkAhashi, Chief of the Physical Meteorology Laboratory, for his suggestion of the problem to me and his many valuable helps.

\section{References}

Findeissn, W., 1940: Über die Entstehung der Gewitterelektrizität. Met. Z. 57, 201.

FINDeIsen, W., 1943: Untersuchungen über die Eissplitterbildung an Reifschichten. ibid, 60, 145.

Kufttner, J., 1950: The electrical and meteorological conditions inside thunderclouds. J. Met., 7, 322.

MaLAN, D.J. and B.F.J. Schonland, 1951: The electrical processes in the intervals between the strokes of a lightning discharge. Proc. Roy. Soc. A, 206, 145. The distribution of electricity in thunderclouds. ibid., A, 209, 158.

MAson, B.J.. 1953 - A critical examination of theories of charge generation in thunderstorms. Tellus, 5, 446-460.

Physical Meteorology Laboratory, Met. Res. Inst., 1953: The last report of the cloud seeding experiments at Mt. Shirane (In Japanese). Tokyo Electric Power Co.

Richardson, L. F., 1926: Atmospheric diffusion shown on a distence-neighbour Graph. P.R.S.A., 110, 709 .

Sutron, O.G., 1949: Atmospheric turbulence. McGraw-Hill, 137.

TAKAGASHI, Y., 1941: On the graphical solution of the problems of the diffusion by turbulence and of the conduction of heat (In Japanese). J. Met. Soc. Japan Ser. II, 19, 321.

Takahashi, Y., 1954: On the cloud seeding experiments in Kanto and Chubu Districts in the summer of 1952. Pap. Met. Geophys., 5, 165-172.

Wrommann, H., 1952: Zur Theorie des Gewitter. Arch Met. Geoph. Biokl. A. Bd., 5, Heft 2.

Workman, E.J. and S.E. Reynolds, 1950: Thunderstorm research programme at New Mexico School of Mines. Proc. Conf. on Thund. Elect. Chicago, 129. 


\title{
人工降雨実験中の発雷時刻について
}

\author{
内田英 治
}

1952 年 8 月東京電力人工降雨実駗中飞群馬県白根山より沃化銀煙を Seeding した時にその煙の流路

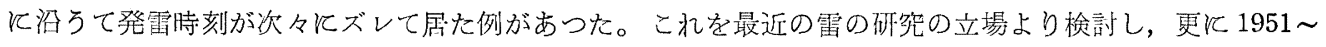
1956 年の期間飞起つた雷の報告をもと飞分析して，果してこれが Seeding の影響か否かをしらべた。

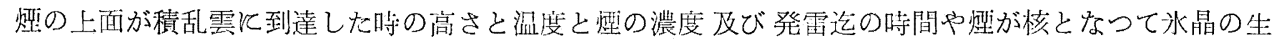
長等も詳しく檢討した。 